\title{
Human Development in Nigeria
}

\author{
Ene Blessing Ita \\ Institute of Social Sciences Istanbul Aydin University, Besyol, \\ Inonu Cd. No:38, 34295 Kucukcekmece/Istanbul, Turkey
}

\begin{abstract}
Human development in Nigeria has been a topic for research by many researchers based on the consistent poor Human Development feedbacks which is seen in the yearly HDR reports by the United Nations Development Programme (UNDP). The research focuses on the Human Development in Nigeria using the three main indicators which include education, life expectancy and income. The researcher collected data from the yearly Nigeria HDR reports from the UNDP. Data were also collected Nigeria Ministry of Education, World development indicators and Nigeria Bureau of statistics. Evident from the study shows that human development is quite low. Nigeria is a low human developed country. Despite the abundant of both natural and human resources, the development rate in Nigeria is very slow and pathetic. Education, health and income per head is Nigeria is at a staggering low point with several parts of Northern Nigeria lives below the US\$1.50 per day poverty line while education is at a very critical low. The result also shows that inequality gap in Nigeria is one of the highest in Africa. In comparison to other West Africa countries like Ghana, Togo and Mali which were studied, Nigeria is still low.
\end{abstract}

Keywords: Human development, Human development index, Education, Health, Life expectancy, income DOI: $10.7176 / \mathrm{JAAS} / 61-06$

Publication date: February $29^{\text {th }} 2020$

\section{Introduction}

Human Development has become prominent and is one of the most important variables to check effective growth of a system. There is a direct linkage between growth of an economy and Human Development of the same economy. Human Development is the situation whereby individuals are allowed or given leverages to make choices, positive choices to increase the level of their total wellbeing. Kubalu et al (2017) opined that the social development of every society is very critical but political entities in the world especially in less developed countries like Nigeria do not invest much of the annual budget on social development which is critical to Human Development. Most times researchers try to examine growth in terms of constant increasing GDP (gross domestic product) annually while they ignore the Human Development of the citizens in the society. Adelakun (2011) further wrote that society depends on the society's increase in productivity levels as its major source of output which is measured per capita.

Human Development is a critical agent of development. The most important way and initiative which can be used for improving the human living based on living quality life is the provision of good education and provision of essential health services. The place where the human resources in a country are healthy and well trained is on a positive path to growth and development.

Nigeria is a constantly growing nation in the place of human resources. The nation is the most populous African nation with abundant natural resources. Adelakun (2011) argues that despite the abundant resources in Nigeria both in human resources and natural resources, the country has been unable to reach the level it should be. The health system is impoverished, security levels is alarming, education is constantly declining. Omolara (2017) opined that the performance of the Human Development indicators in Nigeria is so alarming compared to the indicators with other developing countries.

\section{Human development}

Human Development is a critical aspect of a fully developed state in all ramifications. Omolara (2017) citing Ranis (2004) argued that for long term development to be achieved, Human Development is a necessary prerequisite. A country with high physical growth which is not followed by high levels in Human Development will one day find out that their growth will eventually be unsustainable. The view of achieving growth first ad worry about human development later is one of the major flaws many developing countries of the world still follow. Omolara (2017) opined that the continuous improvement in education, health and the living standard should be a priority to policy makers. Osmani (2016) quoted Amartya Sen's concept of Human Development which focuses on Human capability. The author wrote that increasing the extent at which citizens can improve. Sen also wrote that human development is the rate at which the citizens of a country can get or have access to things of value. Every human being should be given the same opportunity and platform to enjoy life of value.

Human development also involves removing any obstacles which tends to block the freedom of people, the ability to make choices and truncating the right to use the ability to reason properly. Osmani (2016) also quoted 
Mahbub ul Haq who defined human development as the expansion of people's freedom to line long.

Human Development is creating and ample channeling of opportunities and increasing the width and the ability in using human capabilities. It is critical of the choices people make to ensure they have a sustainable livelihood. Human Development also focuses on the process of participation and it is seen in all the countries of the world.

\subsection{Theories of Human Development}

Human capital theory

Tan (2014) defines human capital as productive wealth which is embodied in labor, skills and knowledge and it refers to any stock of knowledge or the innate acquired characteristics a person has that contributes to his or her economic productivity. Adelakun (2011) opines that human capital is the stock of capital that increases in a period when only gross investment exceeds depreciation with the passage of time. Human capital corresponds to productivity. It enables us to think of not only the years of schooling but also of a variety of other characteristics as part of human capital investment.

Tan (2014) opined that human capital theory suggested that education increases the productivity and earnings of individuals which shows that education is a critical investment. According to Tan (2014), the investment is not only crucial for individuals but it is also the key to the economic growth of a country. The author quoted Alfred Marshall who wrote that, "The most valuable of all capital is that invested in human beings". Adelakun (2011) also described human capital theory that view schooling and training as investment in skills and competence. He argued that based on national expectation or return on investment, individuals make decision on the education and training they receive as a way of augmenting their productivity.

Modernization theory

Adelakun (2011) opined that the modernization theory focuses on how education transforms individuals value, belief and behavior. Exposure to modernization institutions such as schools, factories and mass media inculcate modern values and attitudes. The attitude include openness to new idea, independence from traditional authorities, willingness to plan and calculate further exigencies and growing sense of personal and social efficacy. Theorist of modernization opined that the normative and attitudinal changes continue throughout the life cycle which is permanently altering the individuals relationship with the social structure. The greater the number of people exposed to modernization institutions, the greater the level of individual modernity attained by the society.

Dependency theory

Reyes (2001) opined that the theory of dependency was first analyzed by Raul Prebisch and it states that in order to create conditions of development within a country, it is necessary;

i. To control the monetary exchange rate, placing more governmental emphasis on fiscal rather than monetary policy.

ii. To promote a more effective governmental role in terms of national development

iii. To create a platform of investment, giving a preferential role to national capitals

iv. To allow external capitals following priorities already established in national plans for development

v. To promote a more effective internal demand in terms of domestic markets as a base to reinforce the industrialization process

\subsection{Human Development Report}

Human Development report is an editorially publications which is autonomous in nature commissioned by the United Nation development programme (UNDP). It is an annual exercise which acts as an important tool for raising awareness about Human Development around the world.

Human Development report is an editorially publications which is autonomous in nature commissioned by the United Nation development programme (UNDP). It is an annual exercise which acts as an important tool for raising awareness about Human Development around the world.

Sabrina (2010) opine that the first Human Development report was commissioned and published by the UNDP in 1990 and it gave clear and fundamental articulation of the concept of Human Development. It is the only report that focus on the concepts and measures of Human Development and hence it is the background that brought about the framework of Human Development. The basic definition of Human Development was explained holistically in the 1990 HDR which focus on the theme "Concept and measurement of Human Development". People are the real wealth of a nation was the key aspect of the report and the basic objective of development is to create an enabling environment for people to live long, healthy and creative lives. The report also focused on the process and the levels of achieving well-being, it clarifies the concept of freedom in the different paradigm and provides important qualification and classifications. 


\subsection{Human Development index}

Biswas and Caliendo (2007) opined that the HDI assesses how well countries are doing in terms of non-income measures. It calculates the simple average of life expectancy, education and GDP indexes. The link between economic growth and Human Development can only be sort out in comparison of basic life indexes for more detailed information which can not be gotten in studying yearly gross domestic product (GDP)

Graham (2010) wrote that HDI provides an opportunity for the international development community to reevaluate the ways by which welfare is measured and human progress. Graham defined it as a simple statistic of life expectancy, education and per capita indicators which are used to rank countries based on Human Development. .

HDI is a three-dimensional tool used in measuring Human Development. Kovacevic (2011) and Graham (2010) opined that HDI was conceived using three basic dimensions and they are;

1. Longevity (long and healthy life)

2. Education (knowledge)

3. Living standards (a decent standard of living)

\section{Human Development in Nigeria}

Based on the last Human Development report (2016) and the Human Development Index of 2016, the rank of Nigeria was 152 in a list of 188 countries. The yearly HDI report gave Nigeria a score of 0.512 .

Table 1: Nigeria's Human Development index (1990-2015)

\begin{tabular}{|l|l|l|l|l|l|}
\hline Years & $\begin{array}{l}\text { Life expectancy } \\
\text { at birth }\end{array}$ & $\begin{array}{l}\text { Expected year } \\
\text { of schooling }\end{array}$ & $\begin{array}{l}\text { Mean years of } \\
\text { schooling }\end{array}$ & $\begin{array}{l}\text { GNI per capita } \\
\text { (PPPS) }\end{array}$ & HDI value \\
\hline 1990 & 46.1 & 6.7 & & 2,743 & \\
\hline 1995 & 46.1 & 7.2 & & 2,529 & \\
\hline 2000 & 46.6 & 8.0 & & 2,378 & \\
\hline 2005 & 48.7 & 9.0 & 5.2 & 3,606 & 0.466 \\
\hline 2010 & 51.3 & 9.6 & 5.2 & 4,834 & 0.500 \\
\hline 2011 & 51.7 & 9.7 & 5.5 & 4,940 & 0.507 \\
\hline 2012 & 52.1 & 9.8 & 5.7 & 5,035 & 0.514 \\
\hline 2013 & 52.4 & 10.0 & 5.9 & 5,173 & 0.521 \\
\hline 2014 & 52.8 & 10.0 & 5.9 & 5,443 & 0.525 \\
\hline 2015 & 53.1 & 10.0 & 6.0 & 5,443 & 0.527 \\
\hline
\end{tabular}

Source: UNDP, 2016

The report shows that Human Development in Nigeria is at the critical lowest point because Nigeria is part of the countries in low development countries (LDC) based on the Human Development Index (Anas et al, 2017). Nigeria has an estimated population of 200 million people and it accounts for almost half of the population in West Africa. According to Abdu (2017), Nigeria has the largest young people globally with almost $65 \%$ of the population under 30 years which is positive based on the amount of people who can work. Nigeria is blessed with abundance of natural wealth and resource. As the largest exporter of natural gas and crude oil in Africa and the fifth largest in the world, it shows that there is constant increasing revenue from the sector to increase the Gross Domestic Product (GDP) of Nigeria. The pool of natural, mineral and human resources embedded in the country is so large to postulate that in the presence of good and progressive political leadership structure, the rate of economic growth and intense Human Development which is the key aspect of prosperity and critical to sustainability would have been seen in Nigeria long ago. (Adelakun, 2011).

The rate of the increase in human development boils down to the fact that the social development sector have consistently seen decrease in budget allocations in Nigeria. Anas et al (2017) wrote that despite the threefold increase in the total expenditure by government in the public sector after Nigeria started practicing democratic system of government, governmental spending on health and education is still low. Health sector allocation has declined with time if we consider that the percentage of budget allocation to the health sector is $0.98 \%$ of the overall GDP can be equated to other smaller countries in the West and Central Africa. Based on the educational figures in Africa which average share of educational figures in GDP equals 5.7\% and that of government budget equals $19.6 \%$.

Despite the persistency in prioritizing human development in Nigeria especially in the education and health sector, Nigeria is still ranked poorly in human development. Abdu (2017) further wrote that Nigeria position and figure based on human development is quite disappointing which is seen in the rate of unemployment and job availability and declining state of the educational and health sector and the difficulty seen by citizens of Nigeria when it comes to get access to health and education which makes Nigeria to remain low in ranking in human development. 
3.1 Challenges of Human Development in Nigeria

Chikwe et al (2015) gave three challenges facing Nigeria based on human development and they are low rating in human development indices, brain drain and underemployment.

- Low rating in Human Development Indices - Based on the tables we have discussed about, Nigeria Human Development indices is only better than 22 countries which is based on the 2016 Human Development Report. It is am indication of a very poor state of human development considering the amount of human resource and natural/mineral resource that country has.

- Brain Drain - Based on the HDR report of 2006, an estimation of 21,000 doctors are practicing in the United States of America which is worrisome because of the steady decline of doctors and practitioners of medicine in Nigeria. Brain drain is not just an unfortunate precedent in the health sector alone, it is associated with other sectors in Nigeria.

- Underemployment - Chikwe et al (2015) wrote that the utilization and providing a good educational development strategy and providing a habitable environment where the products of the educational system can function well. Yearly, universities in Nigeria churn out graduates without having jobs for the growing population. The place of job creation and instilling the mindset of wealth creation and service providers is very key.

\subsection{Education in Nigeria}

The old 6-5-2-4 educational system was inherited by Nigeria from the colonial masters but was replaced by the 6-3-3-4 education system in 1987. The old 6-5-2-4 focuses on six years of primary education, five years of junior secondary school, two years of senior secondary school and four years of tertiary education. The improved version of the educational system which is 6-3-3-4 is almost the same with the older version but a change in the secondary education system where three years for junior secondary school instead of five years while another three years of senior secondary school instead of two years (Ayodele and Adedokun, 2014)

According to Aluko and Aluko (2015) opine that the new model explain that six years will be spend in primary education. The secondary school which is divided into Junior Secondary School (JSS) and Senior Secondary School (SSS) will be divided into three years each which accumulates to six years and four years of tertiary education. Achuegbue and Ochonogor (2013) opine that the fastest growing education system in Africa is in Nigeria. In 1960, there were only two Universities in Nigeria which were the University of Nigeria, Nsukka and University of Ibadan with the standard enrollment of about 1,400 students. In the space of 40years, the universities in Nigeria have increased in a rate of 3750 percent with a total of 77 universities but the draw back based on increase, is the lack of corresponding increase in financial funding based on research, technology, infrastructure and many more variables. The universities in Nigeria are funded by the federal government, state government, and private owners of private universities.

Table 2: Primary school enrolment in Nigeria (2012-2016)

\begin{tabular}{|l|l|l|l|}
\hline Year & Male & Female & Total \\
\hline 2012 & $13,167,067$ & $11,726,375$ & $24,893,442$ \\
\hline 2013 & $13,500,893$ & $12,657,482$ & $26,158,376$ \\
\hline 2014 & $13,255,789$ & $12,545.408$ & $25,801,197$ \\
\hline 2015 & $13,393,310$ & $12,049,225$ & $25,442,535$ \\
\hline 2016 & $13,435,940$ & $12,155,241$ & $25,591.181$ \\
\hline
\end{tabular}

Source: Ministry of Education, Nigeria, (2017)

According to the table and the data collected, there has been consistent increase in the amount of enrolment of school children into schools but without a parallel increase in educational facilities which will aid teaching. The decline in provision of education tools boil down to underfunding and continuous fall in budgetary allocation to education.

Isola and Alani (2012) wrote that despite the continuous size increase of the system, investment in the educational system has been limited and inefficient which is evident in the HDR rank of Nigeria. Nigeria produces graduates yearly who are majorly deficient and lack the requisite skills, know-how needed to gain employment which in turn is needed for economic growth.

The growth in population in Nigeria over the last decade has put so much stress and pressure on the already overstretched public service and infrastructure. The burden of education children and young teenagers is becoming overwhelming because of the non-availability of sufficient infrastructure to carter for the growing population.

An estimated $40 \%$ of Nigeria children from 6-11 years do not attend any form of primary school. The Northern region recording the lowest school attendance rate in Nigeria, which is seen in girls especially (Achugbu and Ochonogor, 2013). Forty seven million children of primary school age are still not in school despite the increase in net enrolment as we saw in table (14) 
The result of increased rate of enrolment has brought about issues in providing quality education and a learning environment which is satisfactory because of the obvious insufficient spread of educational resources in comparison with the ever growing number of student. In come situation, student sit outside or under trees because of lack of classrooms and the ratio of student to teacher is over 100 students per teacher.

The universal basic education scheme (UBE) law was instituted in 2004 to combat the growing issue. The scheme was implemented to provide basic education for every child in Nigeria. Based on the continue increase enrolment and stagnant infrastructure, the UBE is still finding it hard to ensure quality education for all and child education in Nigeria still falls below expectation.

The UBE has achieved much in infrastructural development but the child friendly environment concept for children has not been adequately adopted by many states in Nigeria. Majority of schools in Nigeria especially those in rural areas don't have electricity, clean water and adequate toilet facilities. Averagely in rural settings, there are 600 pupils per toilet in primary schools and less amounts in secondary school. Amount of money invested in basic education in Nigeria is low when juxtaposed with numbers in other West Africa countries.

\subsection{Life expectancy in Nigeria}

Sede and Ohemeng (2015) opined that life expectancy has important implications for the individuals and aggregate human behaviors. According to their study, life expectancy affects growth of the economy, human development, fertility behavior, intergeneration transfer and incentives for pension benefactors. Life expectancy also has implications for public finance and it is crucial to the developing worlds who are earnestly striving to achieve socio-economic progress through investing significantly in the social sectors like health, education, sanitation, environmental management and sustainability. The possibility of high life expectancy is seen in countries with more even distribution of income.

Table 3: Life Expectancy data in HDI (2006-2013)

\begin{tabular}{|l|l|l|l|l|l|l|l|l|l|}
\hline Country & HDI rank & $\mathbf{2 0 0 6}$ & $\mathbf{2 0 0 7}$ & $\mathbf{2 0 0 8}$ & $\mathbf{2 0 0 9}$ & $\mathbf{2 0 1 0}$ & $\mathbf{2 0 1 1}$ & $\mathbf{2 0 1 2}$ & $\mathbf{2 0 1 3}$ \\
\hline Norway & 1 & 80.2 & 80.4 & 80.7 & 80.9 & 81.1 & 81.2 & 81.4 & 81.5 \\
\hline Australia & 2 & 81.3 & 81.6 & 81.8 & 81.9 & 82.1 & 82.2 & 82.4 & 82.5 \\
\hline Switzerland & 3 & 81.4 & 81.6 & 81.9 & 82.0 & 82.2 & 82.3 & 82.5 & 82.6 \\
\hline Netherlands & 4 & 79.7 & 80.0 & 80.2 & 80.4 & 80.6 & 80.8 & 80.9 & 81.0 \\
\hline USA & 5 & 77.8 & 78.0 & 78.2 & 78.4 & 78.5 & 78.7 & 78.8 & 78.9 \\
\hline Brazil & 79 & 72.0 & 72.3 & 72.6 & 72.8 & 73.1 & 73.4 & 73.7 & 73.9 \\
\hline Iraq & 120 & 69.0 & 68.8 & 68.7 & 68.6 & 68.6 & 68.9 & 69.2 & 69.4 \\
\hline Nigeria & 152 & 49.2 & 49.8 & 50.3 & 50.8 & 51.3 & 51.7 & 52.1 & 52.5 \\
\hline
\end{tabular}

Source: UNDP (2016)

In 2013, the life expectancy in Nigeria was 52.5 which is very low in comparison with other developing countries. Abdu (2015) and Sede and Ohemenyi (2015) opined that life expectancy of Nigeria slightly increased but the figures are still lower than other poor states in Africa. Factors like poor nutrition and a critically high level of infant mortality and high maternal rate are seen to be major reasons why there is lowlife expectancy in Nigeria.

\subsection{Income in Nigeria}

Abdu (2017) opined that GNI per capita ppp is an important yardstick in measuring poverty levels and also reflects the total financial strength of a country. The fluctuation of GNI per capita income is a direct representation of the level of growth in an economy and the development of countries based on the per capita incomes of Nigeria showed in the table 4 below, which shows US $\$ 5,750$ per annum, considering the huge economic, human and natural resources, Nigeria is very low.

Table 4: Income indicator (2005-2013)

\begin{tabular}{|l|l|l|l|l|l|l|l|l|l|l|}
\hline HDI rank & Country & $\mathbf{2 0 0 5}$ & $\mathbf{2 0 0 6}$ & $\mathbf{2 0 0 7}$ & $\mathbf{2 0 0 8}$ & $\mathbf{2 0 0 9}$ & $\mathbf{2 0 1 0}$ & $\mathbf{2 0 1 1}$ & $\mathbf{2 0 1 2}$ & $\mathbf{2 0 1 3}$ \\
\hline 1 & Norway & 0.957 & 0.976 & 0.978 & 0.976 & 0.973 & 0.973 & 0.972 & 0.976 & 0.976 \\
\hline 2 & Australia & 0.895 & 0.896 & 0.900 & 0.903 & 0.903 & 0.904 & 0.905 & 0.909 & 0.911 \\
\hline 5 & USA & 0.939 & 0.943 & 0.943 & 0.941 & 0.935 & 0.938 & 0.941 & 0.944 & 0.946 \\
\hline 100 & Tonga & 0.597 & 0.596 & 0.596 & 0.589 & 0.591 & 0.594 & 0.597 & 0.599 & 0.600 \\
\hline 118 & South Africa & 0.701 & 0.708 & 0.711 & 0.715 & 0.712 & 0.715 & 0.718 & 0.720 & 0.720 \\
\hline 152 & Nigeria & 0.551 & 0.555 & 0.574 & 0.573 & 0.578 & 0.582 & 0.589 & 0.596 & 0.601 \\
\hline
\end{tabular}

Source: UNDP (2016)

Living standards in Nigeria is a dual cascade of poverty and gross inequality levels between citizens. Ogbeide and Agu (2015) opined that Nigeria has an increasing rate of poverty incident at the region and national levels. The country also suffers from high rate of unemployment, high disparities in income among people, investment in human capital is low, there is also a high percentage of the population under government welfare, 
migration, brain drain because of failing infrastructures, low GDP and GNI despite the large natural, human and physical resource. Based on the latest indicators and data from UNDP (2009), it shows that 65.9\% of the Nigeria population was poor which accounts to 112.5 million people. The figures are way too high in comparison with the $15 \%$ found in 1960 and the $27.2 \%$ found in 1980 .

Unemployment rate shows an increase from $2.3 \%$ in 1980 to $18.1 \%$ in 2000 . It dropped to $11.8 \%$ in 2004 but climbed to $21.1 \%$ in 2010 and $25 \%$ in 2012 and it is steadily increasing. Poverty is directly dependent on the total level of income of the population in question and the exact level of inequality in the population (Ogbeide and Agu, 2015). In measuring living standards or poverty levels, the international standard is at \$1 to \$2 per day for each individual in a country.

Table 4 gives an overview of the HDR from 2005-2013 using income indicators. GNI per capita ppp was the macroeconomic variable which was put into consideration. According to the data, Nigeria is the number 152 in the list and the 2013 data which shows 0.601 indicates that Nigeria is among the low human development countries. Nigeria has been in that positive of low human development countries for so long which indicates that the income levels in Nigeria is very low among the population

\section{Comparing Human Development in Nigeria to other West Africa states.}

Human Development in West Africa based on available data is the lowest compared to other African regions like South, North and East Africa which have countries in the very high, high and medium Human Development countries. Countries like Algeria, Libya, Seychelles and Tunisia are in the very high and high Human Development countries. Ghana is the only West African country in the medium Human Development countries. Others are languishing in the low Human Development country including Nigeria (UNDP, 2016).

West Africa and Central Africa countries are the poorest and least developed regions in Africa with incidence of poor health, knowledge, very low income, lack of skills, wars and high population growth. One of the biggest drawbacks in many West Africa states is the issue of governance.

\subsection{Comparing Ghana and Nigeria}

The West Africa country of Ghana is bordered in the west by the Ivory Coast while in the north and east are Burkina Faso and Togo respectively. Based on the 2015 UNDP Human Development report, Ghana has a HDI value of 0.579 which makes her the highest country in West Africa based on Human Development. It is positioned at the 139 position out of 188 countries and it is foumd in the medium Human Development category (UNDP, 2016).

Since the inception of the UNDP HDI report, the HDI value of Ghana from1990-2015 has increased by 27.2 percent with 0.455 to 0.579 .

Table 5: Human Development Index of Nigeria and Ghana

\begin{tabular}{|l|l|l|l|l|l|l|}
\hline $\begin{array}{l}\text { HDI } \\
\text { rank }\end{array}$ & Country & $\begin{array}{l}\text { HDI } \\
\text { value }\end{array}$ & $\begin{array}{l}\text { Life expectancy } \\
\text { at birth }\end{array}$ & $\begin{array}{l}\text { Expected year of } \\
\text { schooling }\end{array}$ & $\begin{array}{l}\text { Mean year of } \\
\text { schooling }\end{array}$ & $\begin{array}{l}\text { GNI per capita (PPP } \\
\text { \$) }\end{array}$ \\
\hline 139 & Ghana & 0.579 & 61.5 & 11.5 & 6.9 & 3.839 \\
\hline 152 & Nigeria & 0.527 & 53.1 & 10.0 & 6.0 & 5.443 \\
\hline
\end{tabular}

Source: UNDP (2016)

Table 5 gives an overview of the Human Development indicators used in ranking countries based on development. Ghana is ranked 139 is located in the medium Human Development category while Nigeria with a HDI rank of 152 is found in the low Human Development category. Based on life expectancy, Ghana has an average year of 61.5 years while Nigeria has an average year of 53.1 years. The mean year and expected year of schooling for Ghana are 6.9 and 11.5 respectively compared to Nigeria's 6.0 and 10.0. Nigeria has higher GNI per capita (PPP\$) of US\$5.443 compared to Ghana which is US\$3.839.

Income level in Nigeria is way compared to Ghana. Nigeria is the biggest and largest economy in Africa because of the crude oil deposit and the over 200 million Nigerians. In education and health indicators, Ghana is ahead of Nigeria which is caused by mismanagement of the resources coming into Nigeria, the low rates of educational funding and scanty funding in the health sector and finally, the focus of the government on infrastructural development instead of Human Development in income, health and education.

\subsection{Comparing Togo and Nigeria}

Togo is a West African country with a HDI value of 0.487 for 2015. Based on HDI values, Togo is a low human development country. She occupies a relatively very low position of 166 in a list of 188 countries. There has been a $20.0 \%$ increase in the country's HDI value from 1990-2015. The value has moved from 0.404 to 0.487.

In comparison to Nigeria based on HDI ranking, Nigeria is ranked 152 while Togo is ranked 166. Life expectancy of Nigeria is 53.1 years which is lower than that of Togo which is 60.2 years. Nigeria's HDI value is 0.527 while that of Togo is 0.487 . GNI per capita (PPP \$) is 5,443 for Nigeria and 1,262 for Togo. Based on the table 35 below which gives an overview of both countries, Human Development in Nigeria is higher compared 
to Togo

Table 6: Comparing Nigeria and Togo using HDI indicators.

\begin{tabular}{|l|l|l|l|l|l|l|}
\hline $\begin{array}{l}\text { HDI } \\
\text { rank }\end{array}$ & Country & $\begin{array}{l}\text { HDI } \\
\text { value }\end{array}$ & $\begin{array}{l}\text { Life expectancy } \\
\text { (years) }\end{array}$ & $\begin{array}{l}\text { Expected year of } \\
\text { school (years) }\end{array}$ & $\begin{array}{l}\text { Mean year of } \\
\text { school (years) }\end{array}$ & $\begin{array}{l}\text { GNI per } \\
\text { capita (PPP \$) }\end{array}$ \\
\hline 152 & Nigeria & 0.527 & 53.1 & 10.0 & 6.0 & 5.443 \\
\hline 166 & Togo & 0.487 & 60.2 & 12.0 & 4.7 & 1.262 \\
\hline
\end{tabular}

Source: UNDP (2016)

Based on Table 6, schooling in Togo is lower than that in Nigeria but Nigeria's indicators are quiet low which is a far cry comparing the amount of Gross Domestic Product which comes into Nigeria yearly. The amount allocated to health and education from the Nigeria yearly budget is nothing to write home about while governmental expenditures on health and education depreciate yearly. Currently, Nigeria is suffering brain drain and has the highest volume of medical tourists leaving Nigeria to seek health care in other countries.

\subsection{Comparing Mali and Nigeria}

Mali is another country in the West Africa sub-region of Africa and it is a landlocked area. By landmass, Mali is the eight largest country in Africa with a population of 18 million. The capital of Mali is Bamako and the country is dominantly Muslims ( $90 \%$ of the population).

The country is located in the low Human development position because her value of HDI was 0.442 in 2015 and she occupies the 175 position in a list of 188 countries and territories. The HDI value of Mali has increased from 0.222 to 0.442 in the space of 1990 to 2015 .

Table 7: Comparing HDI indicators of Nigeria and Mali

\begin{tabular}{|l|l|l|l|l|l|l|}
\hline $\begin{array}{l}\text { HDI } \\
\text { rank }\end{array}$ & Country & $\begin{array}{l}\text { HDI } \\
\text { value }\end{array}$ & $\begin{array}{l}\text { Life expectancy } \\
\text { at birth }\end{array}$ & $\begin{array}{l}\text { Expected year of } \\
\text { schooling }\end{array}$ & $\begin{array}{l}\text { Mean year of } \\
\text { schooling }\end{array}$ & $\begin{array}{l}\text { GNI per } \\
\text { capita (PPP \$) }\end{array}$ \\
\hline 152 & Nigeria & 0.527 & 53.1 & 10.0 & 6.0 & 5.443 \\
\hline 175 & Mali & 0.442 & 58.5 & 8.4 & 2.3 & 2.318 \\
\hline
\end{tabular}

Source: UNDP (2016)

Comparing Nigeria and Mali based on Human Development indicators, the HDI ranking of Nigeria is 152 while that of Mali is 175. Nigeria has a value of 53.1, 10.0 and 6.0 for life expectancy at birth, expected year of schooling and mean year of schooling respectively while Mali's life expectancy at birth, expected year of schooling and mean year of schooling are 58.5, 8.4 and 2.3 respectively. Nigeria's GNI per capita is 5.443 while that of Mali is 2.318

Based on Life expectancy at birth, Mali with a smaller GDP and GNI compared to Nigeria has a higher years in Life expectancy because of the over population in Nigeria compared to income and the extent of inequality and lack of consistent improvement based on allocation to the health sector.

\section{Conclusion}

Human development is a critical aspect of a fully developed state in all ramifications. In modern times, human development is a necessary prerequisite to ascertain the socio-economic development of a country. Development is not just about infrastructural growth, an increasing GDP and a good democracy, sincere economic growth is seen in the lives of the citizens of the country based on so many aspects the author wrote as dimensions. The most critical of the aspects focuses on education, health and income. Other key aspects of human development are security, gender equality, Human rights and poverty.

The investment in human development should be at the same level with the investment in physical development in a country. The major different between developed countries, developing countries and underdeveloped countries is the growth in human development in those countries. For a country to be prosperous and grow consistent, human development and economic development must grow together. A good educational system empowers individuals with skills to help them fend for themselves. It also increases the level of research and development and innovation.

Human development is the process of increasing the width of the choices of people and increase in levels of their achieved well being. Human development brings clarification between improving the health of individuals, increasing their knowledge and the ability or capability to use the acquired knowledge for work and to earn a decent living. Human Development focuses on the use of capabilities of human which in turn focuses on the distribution and production of commodities. It is critical of the choices people make to ensure they have a sustainable livelihood. Human development is also a process which involves all participants and humans. It is a fluent process which focuses on all the countries of the world.

In 1990, the total concept of Human Development was established that was after the inaugural release of the first HDR reports by the United Nations which uses Human Development Index to measure the human development growth. The first report of the HDR focused on enlarging people's choices based on health, education and living standard. Human Development is also associated with the right to political freedom, Human 
Right and the self respect of humans. The first according to Sabrina (2002) embodied the main definition of Human development and the vision behind the yearly report. Other reports that came after the 1990 report tried to build up from the first report.

One of the major theories of human development, which is the Human capital theory opine that the growth and investment in education brings about productivity increase in individuals. With the right investment in social development in a country, the economic growth of the country will increase constantly without any draw backs.

The yearly Human development report divided countries into different categories, the very high human developed, high human developed, medium human developed and low human developed countries. the criteria for the division is centered on several four critical indicators in the human development index and they are life expectancy which centers on health, mean year of schooling and expected year of schooling which centers on education and gross national income (GNI) per capita PPP (International dollar) which focuses on income. These indicators are measured based on data collected throughout the year from individual countries and a country by country human development report is released. The last report was released in 2016 and it carried the human development report of 2015. In that report, Norway is the number one human developed country while Nigeria is the 152 human developed country out of 188 countries and territories.

Based on human development, Nigeria is a low human developed country. Despite the abundant of both natural and human resources, the development rate in Nigeria is very slow and pathetic. Education, health and income per head is Nigeria is at a staggering low point with several parts of Northern Nigeria lives below the US $\$ 1.50$ per day poverty line while education is at a very critical low. Despite the consistent growth in Gross domestic product (GDP) because of her immerse oil reserve and position in OPEC (organization of petroleum exporting countries) Nigeria is a very poor country. The inequality gap in Nigeria is one of the highest in Africa. The inequality between the rich and the poor is very high. Based on governance, political administration has been eclipsed with corrupt practices and total absentee action has been in the place of dealing the social developmental problem of Nigeria. Health care is at the critical low while both infant and maternal mortality increases year by year.

Based on the 2015 Nigeria's human development report, Nigeria has a life expectancy from birth of 53.1 years which is very poor based on the standards. Expected year of schooling equals 10.0years, mean year of schooling equals 6.0years, GNI per capita value equals US\$5,443 with an HDI value of 0.521 . The constant decrease in human development in Nigeria boils down to the fact that there have been less emphasis and less budget allocation to the social sector of Nigeria. Anas et al (2017) wrote that despite the threefold increase in the total expenditure by government in the public sector after Nigeria started practicing democratic system of government, governmental spending on health and education is still low. Health sector allocation has declined with time if we consider that $0.98 \%$ of spending on the health sector as a percentage of GDP can be equated to other smaller countries in Sub-Saharan Africa. The average share of education based on GDP 5.7\%and of government is $19.6 \%$. In terms of education spending, Nigeria is one of the lowest in Africa.

Brain drain and underdevelopment are seen as one of the critical reasons for the under-development in Nigeria. The amount of Nigerians who migrate to other countries to seek for better source of income and living is growing rapidly. Annually, more Nigerians, especially the specialized ones move to other countries just for greener pastures because of the depth in development Nigeria is facing. Human right abuse continues to increase while governmental negligence increases with it too.

Based on the data collected, social development is increasing but the development is slow, very slow including the rate of mortality.

In comparison between other West Africa countries, Ghana was seen to be in the medium developed country region and the highest in West Africa. With an HDI ranking 139, Ghana located in the medium human development category compared to Nigeria with a HDI rank of 152 is found in the low human development category. Based on life expectancy, Ghana has an average year of 61.5 years while Nigeria has an average year of 53.1 years. The mean year and expected year of schooling for Ghana are 6.9 and 11.5 respectively compared to Nigeria's 6.0 and 10.0. Nigeria has higher GNI per capita (PPP\$) of US\$5.443 compared to Ghana which is US\$3.839. In comparing Togo to Nigeria based on HDI ranking, Nigeria is ranked 152 while Togo is ranked 166. Life expectancy of Nigeria is 53.1 years which is lower than that of Togo which is 60.2 years. Nigeria's HDI value is 0.527 while that of Togo is 0.487 . GNI per capita (PPP \$) for both countries are 5,443 for Nigeria and 1,262 for Togo. Based on the above comparison, human development in Nigeria is higher in Nigeria compared to Togo with an impoverish healthcare and educational system.

And finally, comparing Nigeria and Mali based on human development indicators, the HDI ranking of Nigeria is 152 while that of Mali is 175 . Nigeria has a value of 53.1, 10.0 and 6.0 for life expectancy at birth, expected year of schooling and mean year of schooling respectively while Mali's life expectancy at birth, expected year of schooling and mean year of schooling are 58.5, 8.4 and 2.3 respectively. Nigeria's GNI per capita is 5.443 while that of Mali is 2.318 . The information above indicates that Nigeria has a better human development compared to Mali. 


\section{Reference}

Achugbu, E. I and Ochonogor,W.C (2013). Education and human capital development through appropriate utilization of information services. African research review, 7(3)30, 75-85

Adelakun, O.J (2011). Human capital development and economic growth in Nigeria. European journal of business and management, 3(9), 24- 38

Ackah, C., Adjasi, C., Turkson, F and Acquah, A (2016). Education, skill and earnings: further evidence from Ghana. Retrieved from http//.www.bookimgs.edu/wp-content/uploads/2016/07/126_WP16_Ackah-et-al-114

Aluko,Y.A and Aluko,O (2012). Human capital development : Nigeria greatest challenge. Journal of management policy and practice, 13(1),50-72

Anas, I.K ., Aminu, M.M and Zainab, S.S (2017). A dynamic analysis of the relationship between human development and economic growth in Nigeria. International journal of advanced studies in economics and public sector management, 5(1), 37-50

Ana, P (2014). Human capital dimension-education, health and economic growth. Retrieved from http//:www.bdigital.ipg.pt/dspace/bitstream/10314/2417/1/\%2b971dc_59847.pdf

Atake, H. E and Amendah, D.D (2018). Porous safety net: Catastrophic health expenditure and its determinants among insured households in Togo. BMC health services research, 18(175), 368-380

Ayodele, J.B and Adedokun, M.O (2014). Towards achieving functional adult literacy in Nigeria. European scientific journal 8(5), 3421-3436

Bafei, P.A (2011). Education in Togo: From its creation until the period of socio-political and economic crisis. International education studies, 4(1), 248-258

Bernadette, O. H ., Innocent, M ., Levison, C and Navr, B.Z (2013). Income and child mortality in developing countries: A systematic review and meta-analysis. Journal of the royal society of medicine, 106(10),408414

Biswas, B and Caliendo, F (2002). A multivariate analysis of the human development index. Economics and finance, paper 244

Blanca, E.F, Franwise, C ., Derek, C ., Christain, A and Kalipso, C (2016). Quality of healthcare in Ghana: Mapping of intervention and the way forward. Ghana medical journal, 50 (4), 238-247

Capelli, C and Vaggi, G (2013). A better indicator for standards of living: The gross national disposable income. DEM working paper series, pp 24-72

Caroline, P (2009). Delivering education for all in Mali. OXFAM international research report, pp 173-193

Chikwe, C.K ., Ogidi, R.C and Nwachukwu, K (2015). Challenges of research and human capital development in Nigeria. Journal of education and practice, 6(28), 345-367

Cooke, E ., Sarah, H and Andy, M (2009). The Ghana poverty and inequality report. $6^{\text {th }}$ Ghana living standard survey.

Dedehouanou, F.A.S and Berthe, A (2013). Institutional arrangements and education service delivery in primary schools in Mali. Journal of African development, 15(1), 189-221

Dodani, S and LaPorte, R.E (2005). Brain drain from developing countries: How can brain drain be converted into wisdom gain. Journal of the royal society of medicine, 98:487-491

Drislan, F.W ., Akpalu, A and Henry, H.J.W (2014). The medical system is Ghana. Yale Journal of biology and medicine, 87:321-326

Gbensugho, A.B (2013). Population growth and employment for socio-economic development in Ghana. Economy of Ghana network, 2(14), 24-26

Graham, C (2010). The challenge of incorporating empowerment into the HDI: Some lessons from happiness economics and quality of life research. United Nations Development programme, human development report, July 2010

Godstime, O.E and Uchechi, S.A (2014). Human capital development and economic growth: The Nigeria experience. International journal of academic research in business and social sciences. 4(4), 234-246

Gomes, O.A and Gasper, D (2013). Human security: A thematic guidance note of regional and national human development report teams. United Nations Development Programme report office, 1-16

Hulme, D (2007). The making of the millennium development goals. Retrieved from https.//www.sustainabledevelopment.un.org/content/documents/773bwpl-wp-1607.pdf/

Hulme, D (2009). The millennium development goals (MDGS): A short history of the world's biggest promise. World poverty institute, working paper 100:1-55

Isola, W.A and Alani, R.A (2012). Human capital development and economic growth: Empirical evidence from Nigeria. Asia economic and financial review, 2(7), 813-827

James, B.S (2002) Development and human security. International journal, 54:306-323

Johnson, A.D ., Lawn, J.E and Ruban, I (2013). Assessing early access to health care and child survival during a health care crisis. BMJ global health, 3(8), 374-394 
Jones, P ., David, H and Daphne, C (2016). The sustainable development goals and business. International journal of sales, retailing and marketing, 5(5), 38-48

Kovacevic, M (2011). Review of HDI critiques and potential improvements. United Nations development programme. Human development reports research paper 2011

Kubalu, A.I ., Aminu, M.M and Zainab, S.S (2017). A dynamic analysis of the relationship between human development and economic growth in Nigeria. International journal of advanced studies in economics and public sector management, 5(1), 968-989

Michael. M (2013). Climate change and human security: the international governance architectures, policies and instruments. The London School of Economics and Political science research online, 28-40

Ogbeide, E. N.O and Agu, D.O (2015). Poverty and income inequality in Nigeria: Any causality? Asian economic and financial review 5(3), 439-452

Omolara, C.A (2017). Inclusive growth and sustainable human development in Nigeria. Advances in social sciences research journal, 4 (7) ,345-353

Oscar, A.G and Gasper, D (2013). Human security: A thematic guidance note for regional and national human development report teams. United nation development programme, human development report, 23-56

Osmani, S.R (2016). The capability approach and Human development : Some reflections. UNDP Human Development report; think piece, 1-24

Pradhan, P ., Costa, L ., Rybak, D ., Lucht, W and Kropp,J (2017). A systematic study of sustainable development goals (SDG) interaction. Earth's future 5, 1169-1179

Reyes, G.E (2001). Four main theories of development: Modernization, dependency, word-system and globalization. Nomadias, revista critica de ciencias sociales jundicae, 2004 (2), 181-205

Sabina, A (2002). Dimension of human development. World development, 30, 1324-1394

Sabina, A (2010). Human development: Definitions, critiques and related concepts. Oxford poverty and human development initiative working paper no 36

Sede, P. I and Ohemeng, W (2015). Socio- economic determinant of life expectancy in Nigeria (1980-2011). Health economics review, 5(2), 56-70

Shakespare, W (2015). Theories of human development. Sage publications, Inc (2015)

Simon, H, O ., Eric, Z ., Ikuho, M ., Tim, C ., Yoshida, T and Magnus, B (2014). Implementing the sustainable development goals (SDGs): An assessment of the means of implementation (MOI). ISAD conference paper; institute for global environment strategies

Siobham, M.L (2009). Human rights and development: a comment on challenges and way forward. Journal of human rights practice, $\mathbf{1}(1), 51-82$

Tan, E (2014). Human capital theory; A holistic criticism. American educational research review, 84(3), 411445

UNDP (2016). Human development report 2016. $\quad$ Retrieved from http//:www.hdr.undp.org/sites/aii/themes/hdr_theme/country-notes?NgA.pdf 